\title{
Study on Empathy among Undergraduate Students of the Medical Profession in Nepal
}

\author{
Krishna Bahadur GC, Sudarshan Paudel* \\ School of Public Health, Patan Academy of Health Sciences, Lalitpur, Nepal \\ Email: *sudarshanpaudel@gmail.com
}

How to cite this paper: GC, K.B. and Paudel, S. (2017) Study on Empathy among Undergraduate Students of the Medical Profession in Nepal. Journal of Biosciences and Medicines, 5, 51-63. https://doi.org/10.4236/jbm.2017.511007

Received: October 6, 2017

Accepted: November 20, 2017

Published: November 23, 2017

Copyright ( $\odot 2017$ by authors and Scientific Research Publishing Inc. This work is licensed under the Creative Commons Attribution International License (CC BY 4.0).

http://creativecommons.org/licenses/by/4.0/

(c) (i) Open Access

\begin{abstract}
Background: The incumbent of medical professional is expected to be socially responsible and emotionally empathetic along with good communication propensity to fasten the doctor-patient relationship. Whilst doctor's proficiency to recognize a patient's perspectives, and convey such an understanding back to the patient; in our case, the empathy and compassion level of promising medical professional is unknown in Nepal. Thus, this study aimed to analyze the compassion and empathy score of final year's undergraduate students of four medical colleges in Nepal. Methods: Self-reported empathy measures were obtained using the Jefferson Scale of Physician-Student version. Results: The degree of empathy for the participants was 97.28 (SD = 14.44 ) with a median score of 96.00 and a range of $44(\mathrm{~min})$ to 133 (max). There was a significant difference on scores of the Jefferson scale of physician empathy between NMC Nepalgunj and BPKIHS $(p=0.00)$ and between NMC Nepalgunj and Manipal Pokhara $(p=0.00)$, as well as between UCMS and Manipal Pokhara $(p=0.044)$. These results were significant at the $95 \%$ confidence interval. Conclusions: The mean empathy score for the Nepali students is lower than medical students from developed countries but almost similar to medical students from other Asian medical students. The female Nepali medical students scored slightly higher than their male counterparts. Thus colleges have to develop academic programs to improve empathy and compassion among medical students through providing adequate time to consult with patient and faculties.
\end{abstract}

\section{Keywords}

Final Year's Medical Students, Compassion and Empathy, Jefferson Scale, Nepal

\section{Background}

All over the world, attitudes of empathy, resilience and emotional support for 
patients have been found to be important parameters in improving the outcome of diseases that affect ill people [1] [2] [3]. Anecdotal observations among stakeholders in health, including patients have supported the assertion that trained health workers have largely lost these virtues, especially in developing countries [4]. Further assertions suggest that volunteer, untrained and partially trained health workers seem to have more empathy and give more emotional support to patients compared to these trained health workers [5]. However, little published evidence exists about the veracity or otherwise of these anecdotes. The outcome of the study will also compare with the result of same studies being carryout in other developing countries.

There is growing concern globally including Nepal about what needs to be done to influence health workers positively to be more empathic, resilient and display more emotional support towards patients [6] [7] [8]. We therefore set out to seek evidence, first among final year medical year students of the medical profession in a cross section. This will serve as baseline for further work on the matter.

The term "empathy" refers to an aspect of personality that has an important role within interpersonal relationships and in facilitating competence in health communication [9]. Communication competence has been cited consistently as a principal element or dimension [10] of quality within the profession of medicine. Empathy is generally accepted as a desirable trait in medics and there are increasing calls to assess the level of empathy at some point during medical school, or prior to admission [10] [11] [12]. Indeed medically competence, socially responsible and emotionally empathetic, is some prominent attribute for incumbent entering the medical profession [2] [13] [14].

Traditionally, medical students accept into medical school primarily on the basis of their achieved academic grades and cognitive skills [15] [16] [17] [18]. An emerging paradigm views empathy as the backbone of patient care and natural human emotion [19] [20] [21] in the context of the doctor-patient relationship. It is the doctor's ability to cognitively recognize a patient's perspectives and experiences, and convey such an understanding back to the patient [22] [23]. This understanding allows the patient to feel respected and validated [24]. Empathy promotes patient and physician satisfaction, contributes to patient enabling and participation, and may improve patient outcomes [10] [25].

There is concern among educators that clinical training may have an adverse effect on medical resident and student empathy. In one cohort of internal medical residents, empathy was measured to be highest at the beginning but decreasing by the end of internship, and remained low through to the end of residency [26] [27].

For this study, the twenty measures of the Jefferson Scale of Empathy. Health Care Provider Student version (JSPE) has been used. This tool has been specifically constructed in the context of the doctor-patient relationship and patient care [7] [28]. Over the past decade, the JSPE has been used in several settings to measure empathy among health professionals. The JSPE enables medical educators to 
evaluate the effectiveness of educational interventions aimed at promoting empathy [29].

It has been reported that medical students become more cynical as they progress through medical school. This can lead to a decline in empathy. We frequently heard that the medical education makes the students "technical literates" but not "educated". Medical colleges have often been dubbed as "ivory towers isolated from the social-cultural value system, National Health Service systems" which applies to the current scenario of teaching of Community Medicine in Nepal as well. Our country is in dire need for rural oriented health care practitioners. It reveals that there is weak relation between health practitioners and patients as well as community. The study will also help to find out the gaps in the doctor-patient relationship and patient care. Thus this study has investigated empathy more closely across the entirety of medical school education of Nepal while controlling for the potential confounding effects of age, gender, ethnicity, religion, marital status etc.

\section{Methods}

Self-reported empathy measures were obtained with the Jefferson Scale of Physician Empathy-Student Version (JSPE-S). A validated 20 items questionnaire with a total score ranging from 20 to 140 . All undergraduate medical students of final year at BP Koirala Institute of Health Sciences (BPKIHS) Sunsari, Manipal Medical College Pokhara, Nepalgunj Medical College (NMC) Bankey and Universal College of Medical Sciences (UCMS) Rupandehi were approached by research team to participate in the study and questionnaire were distributed to all who agreed to participate into study. Only 63 from BPKIHS, 42 from UCMS, 85 from Manipal and 66 from NMC completed questionnaire were returned.

Correlation analysis, multivariate analysis of covariance, and logistic regression analysis were conducted. Prior to analysis the data were cleaned using methods derived from the JSPE-S Professional Manual and Users Guide (2009).

It includes 20 items each answered on a seven-point Likert scale. 10 positively worded items were linked to "perspective taking" and directly scored $(1=$ strongly disagree, 7 = strongly agree). 10 items were negatively worded and reversed scored $(1=$ strongly agree, $7=$ strongly disagree $)$ [30]. Eight of the ten negatively worded items were concerned with "compassionate care" and 2 items were linked to "standing in the patient's shoes." Scores ranged from 20 to 140. Higher values indicate a higher degree of empathy [30].

In accord with JSPE-S methodology statistical analysis was based on simple descriptive statistics using grouped mean scores $($ Min score $=20$; Max Score $=$ 140). To assess significance between variables, two-tailed ' $t$ ' tests (equal variances not assumed) and analysis of variance (ANOVA) were used to confirm validity. Tests were considered statistically significant at the 0.05 level. All analyses were conducted using the latest version of a statistical software package (SPSS V.19)

Participants were explained the purpose of the study. It was also stated that 
participation identity will be kept anonymous and participation was voluntary but returning the questionnaire would be taken as consent to participate. There would be neither reward for participating nor any penalty for not participating in the survey. Printed questionnaire was distributed to the respondents during their regular classes. Participants were given 1 day to complete the study and also asked to take the test individually. The study was cross-sectional in nature and carried out in four Medical Colleges in Nepal 2013. The study was reviewed by the PAHS Ethical Committee.

\section{Results}

The degree of empathy for the Nepalese participants was 97.28 (SD = 14.44) with a median score of 96.00 and a range of $44(\min )$ to $133(\max )$ (see Table 1).

Participant distribution was reasonably homogeneous across Individual colleges and showed a range of mean JSE scores. The lowest was Manipal Pokhara with a score of 93.73 and the highest was NMC Nepalgunj with a score of 104.11 (see Table 2).

Table 1. Descriptive statistics for the student version of the Jefferson scale of physician empathy administered to 256 medical students in Nepal.

\begin{tabular}{cccc}
\hline & & Valid & 256 \\
\cline { 3 - 4 } & & Missing & 0 \\
\hline & Mean & & 97.28 \\
& Median & & 96.00 \\
& Std. Deviation & & 14.44 \\
& Range & & 89 \\
& Minimum & & 44 \\
& Maximum & & 133 \\
& & 25 & 86.00 \\
Percentiles & & 50 & 96.00 \\
& & 75 & 110.00 \\
\hline
\end{tabular}

Table 2. Colleges wise comparisons on scores of the Jefferson scale of physician empathy administered to medical students in Nepal.

\begin{tabular}{|c|c|c|c|c|c|c|c|c|}
\hline & \multirow[b]{2}{*}{$\mathrm{N}$} & \multirow[b]{2}{*}{ Mean } & \multirow{2}{*}{$\begin{array}{c}\text { Std. } \\
\text { Deviation }\end{array}$} & \multirow{2}{*}{$\begin{array}{l}\text { Std. } \\
\text { Error }\end{array}$} & \multicolumn{2}{|c|}{$\begin{array}{l}\text { 95\% Confidence } \\
\text { Interval for Mean }\end{array}$} & \multirow[b]{2}{*}{ Minimum } & \multirow{2}{*}{ Maximum } \\
\hline & & & & & $\begin{array}{l}\text { Lower } \\
\text { Bound }\end{array}$ & $\begin{array}{l}\text { Upper } \\
\text { Bound }\end{array}$ & & \\
\hline BPKIHS & 63 & 93.76 & 11.979 & 1.509 & 90.74 & 96.78 & 44 & 126 \\
\hline UCMS & 42 & 99.00 & 15.027 & 2.319 & 94.32 & 103.68 & 65 & 122 \\
\hline Manipal & 85 & 93.73 & 15.667 & 1.699 & 90.35 & 97.11 & 70 & 133 \\
\hline NMC & 66 & 104.11 & 12.010 & 1.478 & 101.15 & 107.06 & 59 & 125 \\
\hline Total & 256 & 97.28 & 14.444 & 0.903 & 95.50 & 99.06 & 44 & 133 \\
\hline
\end{tabular}


There was a significant difference on scores of the Jefferson scale of physician empathy between NMC Nepalgunj and BPKIHS $(p=0.00)$ and between NMC Nepalgunj and Manipal Pokhara $(p=0.00)$, as well as between UCMS and Manipal Pokhara $(p=0.044)$ (see Table 3 ). These results were significant at the $95 \%$ confidence interval. Further analysis utilizing additional information about the make-up of these colleges (e.g. gender, marital status, etc.) revealed no other significant correlations.

BPKIHS and Manipal colleges lies in hilly region of Nepal and rest two colleges lies in tarai plain, sharing boarder with India. All four colleges boarded students from Nepal, India and other South East Asian Countries. While comparing the scores of the Jefferson Scale among colleges, the score of BPKIHS is significant with NMC. The score of UCMS is significance with Manipal. The score of Manipal is significant with NMC and UCMS.

\subsection{Sex}

Previous studies have shown a significant difference in empathy scores between men and women-with women generally scoring higher than men (JSE, 2009). For the Nepalese participants no significant differences were observed between the sexes (see Table 4) although women had a slightly higher mean score (98.74) compared to men (96.11) (see Table 5).

Unusually, the histogram of mean JSE scores for women (see Figure 1 and Figure 2) reveals 2 peaks (one at $\sim 85$ and one at $\sim 115$ ) which suggest there may be a significant difference between different groups of women. Further analysis

Table 3. Multiple comparisons on scores of the Jefferson Scale of physician empathy administered to Medical Students in Nepal.

\begin{tabular}{ccccccc}
\hline \multirow{2}{*}{$\begin{array}{c}\text { (I) College } \\
\text { Code }\end{array}$} & $\begin{array}{c}\text { (J) College } \\
\text { Code }\end{array}$ & $\begin{array}{c}\text { Mean } \\
\text { Difference (I-J) }\end{array}$ & $\begin{array}{c}\text { Std. } \\
\text { Error }\end{array}$ & Sig. & \multicolumn{2}{c}{$95 \%$ Confidence Interval } \\
\cline { 6 - 7 } BPKIHS & UCMS & -5.238 & 2.754 & 0.058 & -10.66 & 0.18 \\
& Manipal, & 0.032 & 2.298 & 0.989 & -4.49 & 4.56 \\
& NMC & $-10.344^{*}$ & 2.435 & 0.000 & -15.14 & -5.55 \\
& BPKIHS & 5.238 & 2.754 & 0.058 & -0.18 & 10.66 \\
\multirow{2}{*}{ UCMS } & Manipal & $5.271^{*}$ & 2.607 & 0.044 & 0.14 & 10.41 \\
& NMC & -5.106 & 2.728 & 0.062 & -10.48 & 0.27 \\
& BPKIHS & -0.032 & 2.298 & 0.989 & -4.56 & 4.49 \\
\multirow{2}{*}{ Manipal } & UCMS & $-5.271^{*}$ & 2.607 & 0.044 & -10.41 & -0.14 \\
& NMC & $-10.377^{*}$ & 2.268 & 0.000 & -14.84 & -5.91 \\
& BPKIHS & $10.344^{*}$ & 2.435 & 0.000 & 5.55 & 15.14 \\
& UCMS & 5.106 & 2.728 & 0.062 & -0.27 & 10.48 \\
NMC & Manipal & $10.377^{*}$ & 2.268 & 0.000 & 5.91 & 14.84 \\
\hline
\end{tabular}

${ }^{\star}$ The mean difference is significant at the 0.05 level. 


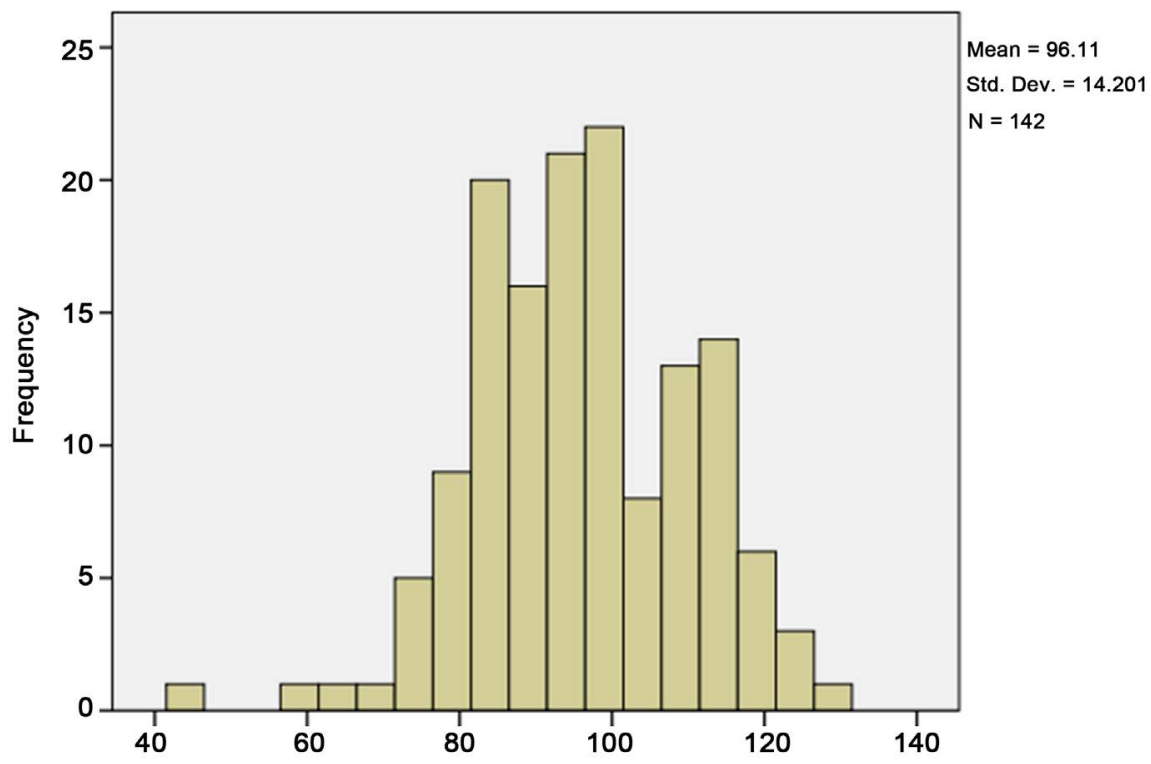

Figure 1. The histogram of mean JSE scores for male respondents.

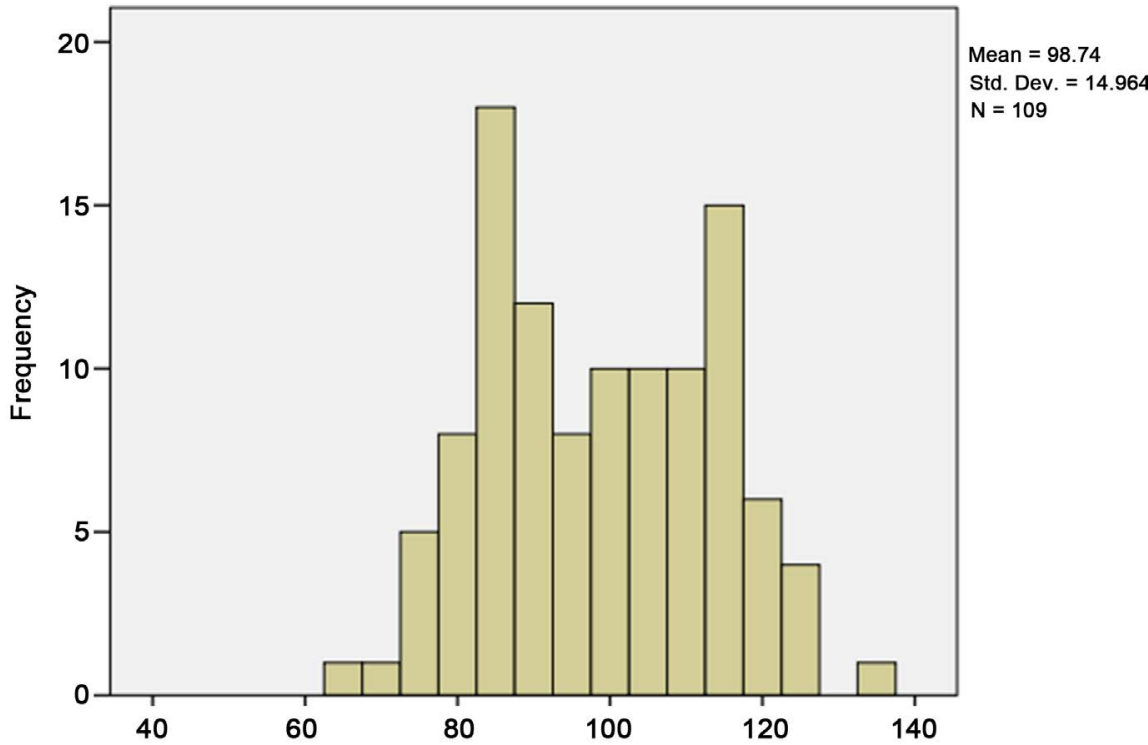

Figure 2. The histogram of mean JSE scores for female respondents.

Table 4. Sex wise independent samples test on scores of the Jefferson scale of physician empathy.

\begin{tabular}{|c|c|c|c|c|c|c|c|c|c|}
\hline & \multicolumn{2}{|c|}{$\begin{array}{l}\text { Levene's Test } \\
\text { for Equality } \\
\text { of Variances }\end{array}$} & \multicolumn{7}{|c|}{ t-test for Equality of Means } \\
\hline & \multirow[t]{2}{*}{$\mathrm{F}$} & \multirow{2}{*}{ Sig. } & \multirow[t]{2}{*}{$\mathrm{t}$} & \multirow{2}{*}{$\mathrm{df}$} & \multirow{2}{*}{$\begin{array}{c}\text { Sig. } \\
\text { (2-tailed) }\end{array}$} & \multirow{2}{*}{$\begin{array}{l}\text { Mean } \\
\text { diff. }\end{array}$} & \multirow{2}{*}{$\begin{array}{l}\text { Std. } \\
\text { Error } \\
\text { diff. }\end{array}$} & \multicolumn{2}{|c|}{$\begin{array}{c}95 \% \text { CI of the } \\
\text { Difference }\end{array}$} \\
\hline & & & & & & & & Lower & Upper \\
\hline $\begin{array}{c}\text { Equal variances } \\
\text { assumed }\end{array}$ & 2.298 & 0.131 & -1.421 & 249 & 0.157 & -2.630 & 1.851 & -6.276 & 1.016 \\
\hline $\begin{array}{c}\text { Equal variances } \\
\text { not assumed }\end{array}$ & & & -1.411 & 226.148 & 0.160 & -2.630 & 1.864 & -6.304 & 1.043 \\
\hline
\end{tabular}


Table 5. Sex wise comparisons on scores of the Jefferson scale of physician student empathy.

\begin{tabular}{ccccc}
\hline sex & $\mathrm{N}$ & Mean & Std. Deviation & Std. Error Mean \\
\hline Male & 142 & 96.11 & 14.201 & 1.192 \\
Female & 109 & 98.74 & 14.964 & 1.433 \\
\hline
\end{tabular}

exploring the influence of a particular variable showed no significant differences. However, it is worth noting that the college with the lowest mean empathy score (Manipal Pokhara) and the lowest median score (88) is also the college with the highest number of women $(n=53 / 88)$. This may go some way towards explaining the lower peak on the histogram but will require further, more detailed, statistical analysis.

\subsection{Marital Status}

The effect of marital status on empathy was difficult to assess as the two groups were very unevenly distributed (222 married: 17 single). The mean JSE score for single participants was higher (97.53) than the mean for married participants (91.35) but this was not statistically significant $(p=0.079)$ (see Table 6).

There were a lot of missing data for age (57/256) which made any statistical analysis difficult. In addition, the remaining 199 individual data-sets were very closely distributed-179 of the participants were aged between 22 and 27. If there were a particular reason why age might be relevant, e.g. people holding different positions relating to age or in different age-related college classes this might be worth pursuing, but with the current data-set is difficult to use age groupings without knowing the context.

There was a very uneven distribution for religion with the vast majority of respondents being Hindu (189/241). No further statistical analysis was conducted as any results would be adversely effected by the disproportionate distribution. The mean scores for each religion are shown below for interest only (Table 7).

\section{Discussion}

Clinician empathy is a key communication skill that forms a part of patient-centred care; a broad approach to clinical work that has emerged in the past couple of decades and has been formalised and included in many codes of conduct and guidelines published by medical colleges [19] [20] [21] [31] [32] [33]. The key principle of patient-centred care is that the clinical process aims to focus on the patient rather than their disease, test results or possible interventions [25]. A clinician undertaking patient-centred care would consider not just if a treatment is available, but whether it is appropriate for the individual patient considering their culture, lifestyle, preferences and circumstances [34]. Clearly empathy, as it fosters an understanding of the patient experience, is essential in obtaining this information. 
Table 6. Marital status wise scores of the Jefferson scale of physician student empathy.

\begin{tabular}{cccccc}
\hline & Marital Status & N & Mean & Std. Deviation & Std. Error Mean \\
\hline \multirow{2}{*}{ Totals } & Married & 17 & 91.35 & 13.153 & 3.190 \\
& Single & 222 & 97.53 & 14.479 & 0.972 \\
\hline
\end{tabular}

Table 7. Religion wise scores of the Jefferson scale of physician student empathy.

\begin{tabular}{|c|c|c|c|c|c|c|c|c|}
\hline & \multirow{2}{*}{$\mathrm{N}$} & \multirow{2}{*}{ Mean } & \multirow{2}{*}{$\begin{array}{c}\text { Std. } \\
\text { Deviation }\end{array}$} & \multirow{2}{*}{$\begin{array}{l}\text { Std. } \\
\text { Error }\end{array}$} & \multicolumn{2}{|c|}{$\begin{array}{l}\text { 95\% Confidence } \\
\text { Interval for Mean }\end{array}$} & \multirow{2}{*}{ Minimum } & \multirow{2}{*}{ Maximum } \\
\hline & & & & & $\begin{array}{l}\text { Lower } \\
\text { Bound }\end{array}$ & $\begin{array}{l}\text { Upper } \\
\text { Bound }\end{array}$ & & \\
\hline Hindu & 189 & 96.96 & 14.044 & 1.022 & 94.95 & 98.98 & 44 & 129 \\
\hline Buddhist & 20 & 96.95 & 16.211 & 3.625 & 89.36 & 104.54 & 70 & 126 \\
\hline Christian & 21 & 100.14 & 17.704 & 3.863 & 92.08 & 108.20 & 75 & 133 \\
\hline Islam & 10 & 93.90 & 10.038 & 3.174 & 86.72 & 101.08 & 79 & 110 \\
\hline Other & 1 & 73.00 & & & & & 73 & 73 \\
\hline Total & 241 & 97.01 & 14.452 & 0.931 & 95.18 & 98.85 & 44 & 133 \\
\hline
\end{tabular}

Evidence is emerging that clinician empathy improves clinical outcomes [31] [35], but diminishes with experience [31] [36] [37] [38]. More empathetic clinicians get better results; but more experienced clinicians tend to show less empathy [39] [40]. These findings suggest both the importance and complexity of empathy in the clinical setting, and raise questions about how empathy can be fostered and maintained to improve clinical outcomes [27].

The mean score for the Nepali sample is lower than that reported by Kataoka et al. for Japanese students [21], Hojat [1] for American medical students (mean $\left.=115, \mathrm{SD}=10, \mathrm{n}=685 ; \mathrm{t}_{(1,083)}=15.8, P<0.01\right)$ and by Alcorta-Garza and colleagues [41] for Mexican medical students (mean $=110.4, \mathrm{SD}=14.1, \mathrm{n}=1022$; $\left.\mathrm{t}_{(1,420)}=8.2, P<0.01\right)$.

Variation in the selection and education of medical students in different colleges, the availability of appropriate role models, and expression of empathy in different cultures [1] [6] can partially explain the empathy score disparity in different cultures. Christian religious cohort have relatively high empathy (100.14) compare to other in our study while married have lesser mean score of empathy (91.35) compare to married (97.53).

The heavily science-oriented teaching learning system and five-year curriculum (liberal arts for two years and medicine for three years) that are characteristic of Nepali medical school may help to explain this situation. Cultural differences, too, may contribute to the difference in scores; Nepali society portrait physicians to be superior profession and unemotional. These factors might affect the expression of empathy among Nepali medical students.

The female Nepali medical students scored slightly higher than their male counterparts. The finding is not consistent with the findings from developed 
countries [2] [6] [37]. The gender difference in empathy has been attributed to intrinsic factors (e.g., evolutionary-biological gender characteristics) as well as extrinsic factors (e.g., interpersonal style in caring, socialization, and gender role expectation) [2] [6].

Approximately 18-year-old high school graduates in Nepal enter medical school [42] directly and spend five years completing undergraduate medical education. Thus, high school students who are interested in going to medical school tend to concentrate heavily on studying science, subjects with little time for extracurricular activities or for development of skills related to "professionalism" before entering medical school [43] [44]. We consider this as one of the reasons why the baseline score on empathy is lower in Nepali students compared with medical students from developed countries.

Most of the medical colleges in Nepal have less time to understand 'life and living' in first two years of medical school. The learning style is monotonous and passive [43]. In the fifth year, at the verge of medical school graduation, students enjoy clinical clerkships and feel proud that because they feel that they finally are given the opportunity to behave as physicians which may have compromised the empathy.

\section{Conclusions}

The medical colleges in Nepal have different academic programs to train ethics, professionalism and empathy. The students from NMC and Manipal colleges have comparatively higher empathy score compared to other two colleges. The overall empathy score of students participants was $97.28(\mathrm{SD}=14.44)$ with a median score of 96.00 and a range of $44(\mathrm{~min})$ to 133 (max). Female students have gained slightly higher (98.74) empathy score than male (96.11), but the difference was not significant. Since our respondents were final year students of undergraduate medical program, they face excessive work load during internship and pressure to pass licensing exam organized by Nepal Medical Council without which they cannot practice as professional.

In the overcrowded outpatient departments of teaching hospital, students have less chance to interact with patient and go beyond the history. Treatment primarily relies on pathological and imaging investigation in overcrowded setting, which gradually seizes the willingness to establish functional relation with patients and co-workers. Students underwent in such setting may not get proper guidance from faculties and seniors resulting decline compassion and empathy.

The study has averred that two medical colleges established in southern region have shared comparative good score than students from rest two colleges from hilly region. However, one of the high empathy scoring medical colleges was affiliated to Government University and other college affiliated with private university.

The further study is expected to investigate the reason, why students score compassion and empathy differently even when they share same academic curricula. However, proper communication training and proper mentoring from 
faculties and seniors could help to improve compassion and empathy among final year medical students.

\section{References}

[1] Hojat, M. (2007) Empathy in Patient Care: Antecedents, Development, Measurement, and Outcomes. Springer, New York.

[2] Del Canale, S., Louis, D.Z., Maio, V., Wang, X., Rossi, G., Hojat, M., et al. (2012) The Relationship between Physician Empathy and Disease Complications: An Empirical Study of Primary Care Physicians and Their Diabetic Patients in Parma, Italy. Academic Medicine, 87, 1243-1249. https://doi.org/10.1097/ACM.0b013e3182628fbf

[3] Hojat, M., Gonnella, J.S., Nasca, T.J., Mangione, S., Vergare, M. and Magee, M. (2002) Physician Empathy: Definition, Measurement, and Relationship to Gender and Specialty. The American Journal of Psychiatry, 159, 1563-1569. https://doi.org/10.1176/appi.ajp.159.9.1563

[4] Marley, J. and Carmen, I. (1999) Selecting Medical Students: A Case Report of the Need for Change. Medical Education, 33, 455-459. https://doi.org/10.1046/j.1365-2923.1999.00345.x

[5] Spiro, H. (2009) Commentary: The Practice of Empathy. Academic Medicine, 84, 1177-1179. https://doi.org/10.1097/ACM.0b013e3181b18934

[6] Hojat, M., Mangione, S. and Nasca, T.J. (2004) An Empirical Study of Decline in Empathy in Medical School. Medical Education, 38, 934-941. https://doi.org/10.1111/j.1365-2929.2004.01911.x

[7] Hojat, M., Gonnella, J.S., Mangione, S., Nasca, T.J., Veloski, J.J., Erdmann, J.B., Callahan, C.A. and Magee, M. (2002) Empathy in Medical Students as Related to Academic Performance, Clinical Competence and Gender. Medical Education, 36, 522-527. https://doi.org/10.1046/j.1365-2923.2002.01234.x

[8] Coulehan, J.L., Platt, F.W. and Egener, B. (2001) "Let Me See If I Have This Right...": Words That Help Build Empathy. Annals of Internal Medicine, 135, 221-227. https://doi.org/10.7326/0003-4819-135-3-200108070-00022

[9] Stewart, M. (2001) Towards a Global Definition of Patient Centred Care. British Medical Journal, 322, 444-445. https://doi.org/10.1136/bmj.322.7284.444

[10] Redmond, M.V. (1985) The Relationship between Perceived Communication Competence and Perceived Empathy. Communication Monographs, 52, 377-382. https://doi.org/10.1080/03637758509376119

[11] Hojat, M., Louis, D.Z., Markham, F.W., Wender, R., Rabinowitz, C. and Gonnella, J.S. (2011) Physicians' Empathy and Clinical Outcomes for Diabetic Patients. Academic Medicine, 86, 359-364. https://doi.org/10.1097/ACM.0b013e3182086fe1

[12] Brown, J. (2008) How Clinical Communication Has Become a Core Part of Medical Education in the UK. In: Medical Education, Vol. 42, Blackwell Publishing Ltd., 271-278. https://doi.org/10.1111/j.1365-2923.2007.02955.x

[13] Makoul, G. and Schofield, T. (1999) Communication Teaching and Assessment in Medical Education: An International Consensus Statement. Patient Education and Counseling, 37, 191-195.

[14] Wen, D., Ma, X., Li, H., Liu, Z., Xian, B. and Liu, Y. (2013) Empathy in Chinese Medical Students: Psychometric Characteristics and Differences by Gender and Year of Medical Education. BMC Medical Education, 13, 130. 
[15] Newton, B.W., Barber, L., Clardy, J. and Cleveland, E. (2008) Is There Hardening of the Heart during Medical School? Academic Medicine, 83, 244-249. https://doi.org/10.1097/ACM.0b013e3181637837

[16] Rao, R.H. (2006) Perspectives in Medical Education-2. A Blueprint for Reform of Medical Education in Japan. The Keio Journal of Medicine, 55, 81-95. https://doi.org/10.2302/kjm.55.81

[17] Williams, B., Sadasivan, S., Kadirvelu, A. and Olaussen, A. (2014) Empathy Levels among First Year Malaysian Medical Students: An Observational Study. Advances in Medical Education and Practice, 5, 149-156. https://doi.org/10.2147/AMEP.S58094

[18] Kulkarni, M.V. and Pathak, S. (2016) Assessment of Empathy among Undergraduate Medical Students. Journal of Education Technology in Health Sciences, 3, 23-27.

[19] Shashikumar, R., Chaudhary, R., Ryali, V.S.S.R., Bhat, P.S., Srivastava, K., Prakash, J. and Basannar, D. (2014) Cross Sectional Assessment of Empathy among Undergraduates from a Medical College. Medical Journal Armed Forces India, 70, 179-185.

[20] Tariq, N. and Tariq, R. (2017) A Quantitative Study of Empathy in Pakistani Medical Students: A Multi-Centered Approach. Journal of Primary Care \& Community Health, 1-6. https://doi.org/10.1177/2150131917716233

[21] Kataoka, H.U., Koide, N., Ochi, K., Hojat, M. and Gonnella, J.S. (2009) Measurement of Empathy among Japanese Medical Students: Psychometrics and Score Differences by Gender and Level of Medical Education. Academic Medicine, 84, 1192-1197. https://doi.org/10.1097/ACM.0b013e3181b180d4

[22] Beckman, H.B., Markakis, K.M., Suchman, A.L. and Frankel, R.M. (1994) The Doctor-Patient Relationship and Malpractice: Lessons from Plaintiff Depositions. Archives of Internal Medicine, 154, 1365-1370. https://doi.org/10.1001/archinte.1994.00420120093010

[23] Bikker, A.P., Mercer, S.W. and Reilly, D. (2005) A Pilot Prospective Study on the Consultation and Relational Empathy, Patient Enablement, and Health Changes over 12 Months in Patients Going to the Glasgow Homoeopathic Hospital. Journal of Alternative and Complementary Medicine, 11, 591-600. https://doi.org/10.1089/acm.2005.11.591

[24] Rosenfield, P.J. and Jones, L. (2004) Striking a Balance: Training Medical Students to Provide Empathetic Care. Medical Education, 38, 927-933. https://doi.org/10.1111/j.1365-2929.2004.01931.x

[25] Yucel, H. and Acar, G. (2016) Levels of Empathy among Undergraduate Physiotherapy Students: A Cross-Sectional Study at Two Universities in Istanbul. Pakistan Journal of Medical Sciences, 32, 85-90.

[26] Bellini, L.M., Baime, M. and Shea, J.A. (2002) Variation of Mood and Empathy during Internship. JAMA, 287, 3143-3146. https://doi.org/10.1001/jama.287.23.3143

[27] Chen, D., Lew, R., Hershman, W. and Orlander, J. (2007) A Cross Sectional Measurement of Medical Student Empathy. Journal of General Internal Medicine, 22, 1434-1438. https://doi.org/10.1007/s11606-007-0298-x

[28] Hojat, M., Mangione, S. and Nasca, T.J. (2001) The Jefferson Scale of Physician Empathy: Development and Preliminary Psychometric Data. Educational and Psychological Measurement, 61, 349-365. https://doi.org/10.1177/00131640121971158 
[29] Stebnicki, M.A. (2008) Empathy Fatigue: Healing the Mind, Body, and Spirit of Professional Counselors. Springer Publishing Company, LLC.

[30] Hojat, M., Gonnella, J.S. and Maxwell, K. (2009) Jefferson Scales of Empathy (JSE): Professional Manual \& User's Guide. Jefferson Medical College-Center for Research in Medical Education and Health Care, Philadelphia.

[31] Vallabh, V. (2011) Psychometrics of the Student Version of the Jefferson Scale of Physician Empathy (JSPE-S) in Final-Year Medical Students in Johannesburg in 2008. South African Journal of Bioethics and Law, 4, 63-68.

[32] Roh, M.S., Hahm, B.J., Lee, D.H. and Suh, D.H. (2010) Evaluation of Empathy among Korean Medical Students: A Cross-Sectional Study using the Korean Version of the Jefferson Scale of Physician Empathy. Teaching and Learning in Medicine, 22, 167-171.

[33] Madiseh, M.R., Tavakol, M., Dennick, R. and Nasiri, J. (2010) Empathy in Iranian Medical Students: A Preliminary Psychometric Analysis and Differences by Gender and Year of Medical School. Medical Teacher, 32, 471-478. https://doi.org/10.3109/0142159X.2010.509419

[34] Kliszcz, J., Sauer, K.N., Trzeciak, B., Nowak, P. and Sadowska, A. (2006) Empathy in Health Care Providers-Validation Study of the Polish Version of the Jefferson Scale of Empathy. Advances in Medical Sciences, 51, 219-225.

[35] Magalhaes, E., Salgueira, A.P., Costa, P. and Costa, M.J. (2011) Empathy in Senior Year and First Year Medical Students: A Crosssectional Study. BMC Medical Education, 11, 52 .

[36] Neumann, M., Edelhäuser, F., Tauschel, D., Fischer, M.R., Wirtz, M., Woopen, C., et al. (2011) Empathy Decline and Its Reasons: A Systematic Review of Studies with Medical Students and Residents. Academic Medicine, 86, 996-1009. https://doi.org/10.1097/ACM.0b013e318221e615

[37] Nunes, P., Williams, S., Sa, B. and Stevenson, K. (2011) A Study of Empathy Decline in Students from Five Health Disciplines during Their First Year of Training. International Journal of Medical Education, 2, 12-17. https://doi.org/10.5116/ijme.4d47.ddb0

[38] Sherman, J.J. and Cramer, A. (2005) Measurement of Changes in Empathy during Medical School. Journal of Dental Education, 69, 338-345.

[39] Hojat, M., Gonnella, J.S., Nasca, T.J., Mangione, S., Veloski, J.J. and Magee, M. (2002) The Jefferson Scale of Physician Empathy: Further Psychometric Data and Differences by Gender and Specialty at Item Level. Academic Medicine, 77, S58-S60. https://doi.org/10.1097/00001888-200210001-00019

[40] Hojat, M., Mangione, S., Nasca, T.J., et al. (2004) An Empirical Study of Decline in Empathy in Medical School. Medical Education, 38, 934-941. https://doi.org/10.1111/j.1365-2929.2004.01911.x

[41] Alcorta-Garza, A., Gonzalez-Guerrero, J.F., Tavitas-Herrera, S.E., Rodrigues-Lara, F.J. and Hojat, M. (2005) Validity of the Jefferson Scale of Physician Empathy among Mexican Medical Students. Salud Mental, 28, 57-63. (In Spanish)

[42] Paudel, S., Gc, K.B., Bhandari, D.B., Bhandari, L. and Arjyal, A. (2017) Health Related Lifestyle Behaviors among Undergraduate Medical Students in Patan Academy of Health Sciences in Nepal. Journal of Biosciences and Medicines, 5, 43-53. https://doi.org/10.4236/jbm.2017.59005

[43] Baral, K.P., Upadhyay, S.K., Bhandary, S., Gongal, R.N. and Karki, A. (2016) Development of Community Based Learning and Education System within Undergraduate 
Medical Curriculum of Patan Academy of Health Sciences. Journal of Nepal Health Research Council, 14, 58-65.

[44] Baral, K., Allison, J., Upadhyay, S., Bhandary, S., Shrestha, S. and Renouf, T. (2016) Rural Community as Context and Teacher for Health Professions Education. $\mathrm{Cu}$ reus, 8, e866. https://doi.org/10.7759/cureus.866 